ROCZNIKI TEOLOGICZNE

Tom LXVI, zeszyt 1 - 2019

DOI:http://dx.doi.org/10.18290/rt.2019.66.1-6

\author{
KS. MIROSŁAW KALINOWSKI
}

\title{
ZASADA POMOCNICZOŚCI \\ W PROMOCJI SPOŁECZNYCH HOSPICJÓW W POLSCE NA PODSTAWIE BADAŃ WŁASNYCH
}

\author{
THE PRINCIPLE OF SUBSIDIARITY IN PROMOTING SOCIAL HOSPICES \\ IN POLAND BASED ON OWN RESEARCH
}

\begin{abstract}
A b s t r a c t. Over the last few decades, the work of palliative and hospice centers in Poland and in the majority of highly developed countries has been evolving in the direction of specialized institutions providing assistance to persons in the terminal stage of cancer. They are part of the country's healthcare system and meet all the criteria of health care institutions. The principle of subsidiarity is the basis for promoting social hospices, and to a large extent, they use the natural capital of civic initiatives and pro-social attitudes. It also influences removing barriers between healthy and sick people, especially those who are dying. The article presents the results of own research among people who are closest to the hospice's charges. Respondents point to existing ways of their influencing the social environment that can contribute to mature attitudes towards suffering and death, such as cooperation among various institutions, scientific and publishing activities, education through mass media, educating school youth, as well as the promotion of palliative care.
\end{abstract}

Key words: subsidiarity principle; hospices in Poland.

Translated by Jan Kobytecki

Pomocniczy charakter każdej wspólnoty wynika z naturalnego pierwszeństwa osoby ludzkiej przed zbiorowością. Społeczność nigdy nie stanowi celu samego w sobie, lecz pełni służebną rolę wobec swoich członków. Rola ta

Ks. prof. dr hab. MirosŁaw KaLINOwSKI - kierownik Katedry Opieki Społecznej, Paliatywnej i Hospicyjnej KUL, dyrektor Instytutu Nauk o Rodzinie i Pracy Socjalnej KUL; adres do korespondencji: ul. Radziszewskiego 7, 20-039 Lublin; e-mail: kalinowskim@kul.pl 
jest wyznaczona przez fakt, że to jedynie człowiek jest samodzielnym bytem osobowym ${ }^{1}$. Oprócz służebności, każda wspólnota odznacza się celowością działań wyznaczona przez potrzeby ludzkie. To właśnie ich zaspokojenie wyznacza wielość, charakter i zakres społeczności ${ }^{2}$.

Działalność ośrodków paliatywno-hospicyjnych w Polsce i w większości krajów wysoko rozwiniętych już od dekady ewoluuje w stronę wyspecjalizowanych placówek świadczących pomoc osobom w terminalnej fazie choroby nowotworowej. Stanowią one część systemu opieki zdrowotnej danego kraju, spełniając wszystkie kryteria zakładów opieki leczniczej. W Polsce istnieje jeszcze wiele hospicjów ${ }^{3}$ podtrzymujących etos posługi samarytańskiej, w którym obecny jest wolontariat systematyczny i akcyjny oraz troska o formację wewnętrzną osób w nim posługujących ${ }^{4}$. Ostatnie lata przynoszą znaczący wzrost sektora prywatnego i publicznego w strukturze hospicjów oraz zespołów paliatywnych ${ }^{5}$, co wiązane jest między innymi ze wzrostem znaczenia zasady pomocniczości w promocji hospicjów w Polsce. Niniejszy artykuł przedstawi najpierw normę subsydiarności, a w dalszej kolejności jej wpływ na kształtowanie postaw społecznych w opinii rodzin podopiecznych Hospicjum Dobrego Samarytanina w Lublinie.

\section{REGUŁY ZASADY POMOCNICZOŚCI}

W katolickiej nauce społecznej zasada pomocniczości jest określana jako norma kształtująca uprawnienia jednostki wobec społeczności ${ }^{6}$, a wspólnoty

\footnotetext{
${ }^{1}$ Cz. STRZeSZEwSKI, Katolicka nauka społeczna, Lublin 1994, s. 517; J. NAGÓRNY, Posłannictwo chrześcijan w świecie wspótczesnym. Świat i wspólnota, t. 1, Lublin 1998, s. 185-187.

${ }^{2}$ Cz. STRZESZEWSKI, Katolicka nauka społeczna, s. 517; zob. K. WOJTYŁA, Katolicka etyka spoteczna, Lublin 2018, s. 73n.

${ }^{3}$ W roku 2017 istniało w Polsce 150 pozarządowych hospicjów (Stowarzyszenia, Fundacje, Caritas, Zgromadzenia Zakonne i Parafie, w tym 27 hospicjów, najczęściej domowych, opartych wyłącznie na zasadzie wolontariatu. „Forum Hospicjów Polskich. List Hospicyjny Wydanie specjalne”, 5 października 2017, s. 3.

${ }^{4}$ Hospicjum Dobrego Samarytanina w Lublinie prowadzi comiesięczne spotkania formacyjne dla wolontariuszy. Kronika Hospicjum Dobrego Samarytanina w Lublinie, Lublin 1990, mps.

${ }^{5}$ Sektor prywatny prowadzi hospicja stacjonarne i oddziały medycyny paliatywnej - 43; hospicja domowe -225 ; poradnie medycyny paliatywnej - 46. Tamże.

${ }^{6}$ Tematowi zasad życia społecznego w ruchu hospicyjnym została poświęcona monografia: M. KALINOWSKI, Wspólnoty nadziei. Realizacja zasad życia społecznego w ruchu hospicyjnym, Lublin 2007.
} 
mniejszej - wobec większej, polegająca na tym, że społeczności większe świadczą uzupełniająca pomoc mniejszym, a wszystkie większe i mniejsze zbiorowości - osobie ludzkiej ${ }^{7}$. Przedstawiona reguła opiera się na tendencji życia wspólnotowego, która jest określana mianem „brania” ze względu na prymat osoby ludzkiej względem wspólnoty i pierwszeństwo mniejszych grup ludzkich przed większymi. W związku z tym formułuje ona obowiązki „od góry” i uprawnienia „od dołu" we wszystkich przejawach i formach życia wspólnotowego ${ }^{8}$.

Zgodnie z zasadą pomocniczości poszczególne osoby, grupy społeczne, a także stowarzyszenia obywatelskie, związki wyznaniowe, rządy poszczególnych krajów i instytucje międzynarodowe są zobowiązane do solidarnego budowania wspólnego dobra ludzkości, na miarę swych kompetencji i zasobów. Rozpatrywanie subsydiarności w perspektywie personalizmu wskazuje na racjonalność wszelkich działań społecznych zarówno w oparciu o zdrowe struktury, jak i zasady ich funkcjonowania. W ten sposób ochrona podmiotowości każdego członka zbiorowości ludzkiej łączy się z troską o roztropne działanie i właściwe wykorzystanie dostępnych środków ${ }^{9}$.

Podobnie jak człowiek szuka wsparcia w różnych wspólnotach w sytuacji, gdy sam nie może spełnić swych zadań życiowych, tak samo każda wspólnota, mniejsza czy niższa, odwołuje się do pomocy społeczności większych czy wyższych tylko wówczas, gdy nie może spełnić określonych zadań, wyznaczonych przez potrzeby jej członków ${ }^{10}$. Zbiorowość mniejsza i większa różnią się liczbą złączonych ze sobą jednostek, a wspólnoty niższe i wyższe zakresem zaspokojenia ludzkich potrzeb ${ }^{11}$.

Normę subsydiarności należy realizować w dwóch aspektach: negatywnym i pozytywnym ${ }^{12}$. Aspekt negatywny polega na poszanowaniu inicjatywy,

\footnotetext{
7 W. Piwowarski, Zasada pomocniczości w encyklice „Pacem in terris”, „Roczniki Teologiczno-Kanoniczne” 12(1965), z. 3, s. 82-83; TENŻE, Zasada pomocniczości w życiu Kościoła, s. 10; Cz. STRZESZEWSKI, Katolicka nauka społeczna, s. 517; T. BORUTKA, J. MAZUR, A. ZwOLIŃSKI, Katolicka nauka społeczna, Częstochowa 2004, s. 62-63; J. KoPEREK, Zasady życia społecznego, w: Stownik społeczny, red. B. Szlachta, Kraków 2004, s. 1605.

${ }^{8}$ W. PIWOWARSKI, Zasada pomocniczości w encyklice „Pacem in terris”, s. 82; TENŻE, ABC katolickiej nauki spotecznej, s. 66-67; TENŻE, Zasada pomocniczości, w: Stownik katolickiej nauki społecznej, s. 197-198.

9 J. NAGÓRnY, Postannictwo chrześcijan, s. 183; J. MAJKA, Etyka spoteczna i polityczna, Warszawa 1993, s. 51-53.

${ }^{10}$ Cz. StrZeszewski, Katolicka nauka społeczna, s. 517-518; G. NoszCZYK, Państwo, w: Jan Pawet II. Encyklopedia nauczania spotecznego, red. A. Zwoliński, Radom 2005, s. 341.

${ }^{11}$ Cz. STRZESZEWSKI, Katolicka nauka spoteczna, s. 517.

${ }^{12}$ ABC katolickiej nauki spotecznej, s. 66-67.
} 
swobody działania, kompetencji i odpowiedzialności jednostek ludzkich w stosunku do społeczności oraz wspólnot mniejszych w stosunku do większych. W ujęciu negatywnym analizowanej reguły pomoc jest zatem paradoksalnie związana z brakiem pomocy. To człowiek jest odpowiedzialny za własny los, więc zbiorowość nie może go „wchłonąć” ani tym bardziej czynić go narzędziem, przedmiotem czy eksploatowanym „towarem”. Jednocześnie większe wspólnoty nie mogą odbierać inicjatywy mniejszym grupom, bo stanowi to naruszenie ich uprawnień do istnienia i rozwoju w ramach społeczeństwa. Dlatego z zasady subsydiaryzmu wynika ważny postulat, aby wszystkie zbiorowości ludzkie utrzymywały się w granicach własnej działalności i nie naruszały zakresów działania innych wspólnot, gdyż każde naruszenie autonomii osoby ludzkiej czy uprawnień mniejszych grup przez większe uniemożliwia spełnienie ich naturalnych zadań, a więc narusza prawo naturalne ${ }^{13}$. Wymienione prawidłowości decydują o tym, że norma subsydiarności stanowi negatywne kryterium dla wszelkiej „odgórnej” działalności w społeczeństwie ${ }^{14}$.

Aspekt pozytywny polega natomiast na świadczeniu pomocy tam, gdzie jest ona konieczna. Nie chodzi tu jednak o pomoc permanentną, lecz doraźną, po to, by jednostka lub grupa ludzka, która nie jest w stanie zrealizować własnych celów, mogła po uzyskaniu niezbędnego wsparcia w dalszym ciągu realizować określone zadania w samodzielny sposób. Ze względu na element subsydiarności wsparcia jest ono określane w społecznym nauczaniu Kościoła jako „pomoc dla samopomocy”15. W związku z tym działalność społeczności większych i lepiej zorganizowanych powinna uzupełniająco pomagać wspólnotom mniejszym i gorzej zorganizowanym, a wszystkie społeczności - większe i mniejsze - mają jedynie subsydiarnie wspierać działania człowieka w jego rozwoju, gdyż ani druga osoba, ani żadna zbiorowość nie są w stanie wypełnić jego zadań. Należy podkreślić fakt, że człowiek tworzy życie społeczne nie po to, by wspólnoty odbierały mu autonomię i inicjatywę, lecz po to, aby świadczyły mu uzupełniającą pomoc w zakresie realizowanych przez niego celów życiowych. Dlatego każda grupa osób realizuje wspólne

\footnotetext{
${ }^{13}$ W. PIWOWARSKI, Zasada pomocniczości w życiu Kościoła, s. 11; CZ. STRZESZEWSKI, Katolicka nauka spoteczna, s. 517-518.

${ }^{14}$ W. PIWOWARSKI, Zasada pomocniczości, w: Słownik katolickiej nauki społecznej, s. 197198.

15 Tenże, Zasada pomocniczości w encyklice „Pacem in terris”, s. 82; TENŻE, Osoba ludzka a społeczność, „Roczniki Filozoficzne” 13(1964), z. 2, s. 39.
} 
wartości we własnym, autonomicznym zakresie działania ${ }^{16}$. Od strony pozytywnej zasada pomocniczości postuluje więc, aby wszystkie społeczności wykonywały własne zadania zgodne $\mathrm{z}$ ich dobrem wspólnym. Im lepiej będą je wykonywały, tym bardziej będzie wzrastać dobro wspólne tych zbiorowości, które z kolei będzie się przyczyniać do większego doskonalenia osób ludzkich jako ich członków. Tym lepiej będzie także rozwijało się dobro wspólne społeczeństwa, a wraz z nim prawdziwy porządek i ład społeczny ${ }^{17}$.

Kanon pomocniczości jest traktowany jako podstawowa norma naturalnoprawna, mająca znaczenie dla różnorodnych aspektów funkcjonowania zbiorowości ludzkich w wyniku spełniania trzech podstawowych funkcji ${ }^{18}$ : przestrzegania autonomii (funkcja gwarancyjno-ochronna), wielowymiarowego wsparcia (funkcja pomocnicza), kształtowania postaw społecznych (funkcja pedagogiczna).

Funkcja gwarancyjno-ochronna wynika z podkreślania realizacji własnych celów, a tym samym odpowiedzialności za własny rozwój „z dołu do góry”. Wspólnota nie może odbierać „własnych zadań” osobie ludzkiej, a społeczność większa - społeczności mniejszej. W ten sposób norma subsydiarności stanowi gwarancję autonomii życia jednostek i małych zbiorowości oraz chroni je przed zniewalającym i wymuszającym systemem dużych struktur społecznych ${ }^{19}$. Na bazie analizowanej normy został sformułowany postulat, aby służenie władz publicznych polegało między innymi na budzeniu inicjatyw społecznych, odpowiedzialności za innych ludzi, koordynowaniu działań jednostek i wspólnot oraz na utrzymywaniu swej działalności w granicach jasno określonych kompetencji. Służenie, które narusza uprawnienia jednostek i mniejszych grup ludzkich w zakresie autonomii, jest działalnością totalitarną, prowadzącą ostatecznie do podeptania godności i praw człowieka ${ }^{20}$.

\footnotetext{
16 TEnŻe, Zasada pomocniczości w życiu Kościoła, s. 10-11.

17 Tamże, s. 11.

18 Tamże, s. 5-23; TENŻE, Zasada pomocniczości w Kościele, w: Kościót - świat - świeccy, Warszawa 1988, s. 42-43; TENŻE, Zasada pomocniczości w demokratyzacji życia kościelnego, „Roczniki Teologiczno-Kanonicze” 35(1988), z. 6, s. 5-20; TEnŻE, Kwestia spoteczna w nauczaniu Jana Pawta II, w: Osoba, Kościót, społeczeństwo, red. I. Dec, Wrocław 1992, s. 333-342; TENŻE, Prawa człowieka w nauczaniu Jana Pawła II, „Więź” 27(1984), nr 5 (307), s. $37-45$.

19 Tenże, Zasada pomocniczości w życiu Kościoła, s. 22; TENŻE, Zasada pomocniczości w Kościele, „Życie Katolickie” 6(1987), nr 7, s. 70-82; J. NAGÓRNY, Posłannictwo chrześcijan, s. 186; J. HöFFNER, Chrześcijańska nauka spoteczna, Warszawa 1999, s. 57.

${ }^{20}$ W. PiwowARsKi, Zasada pomocniczości w życiu Kościoła, s. 22; TENŻE, Zasada pomocniczości w Kościele.
} 
Wielowymiarowe wsparcie. $Z$ jednej strony norma pomocniczości chroni autonomię życia indywidualnego i wspólnotowego, z drugiej jednak - łączy się z interwencyjna pomocą „z góry na dół”. Wsparcie większej zbiorowości ludzkiej może być podjęte $\mathrm{z}$ dwóch powodów. Po pierwsze, w sytuacji gdy poszczególne osoby lub mniejsze grupy nie są w stanie wypełnić powierzonych im zadań. Po drugie, dotyczy to działań, które mogą być podjęte wyłącznie przez większe organizmy społeczne, gdyż powstawanie większych systemów wynika z faktu, że ani pojedyncza osoba, ani mała grupa nie są samowystarczalne ${ }^{21}$. W innych przypadkach nie może zaistnieć sytuacja polegająca na odbieraniu fundamentalnego prawa do realizowania własnych celów. Społeczności silniejsze mają z jednej strony obowiązek poznawania problemów nurtujących ludzi w danym środowisku, a z drugiej - wspierania słabszych poprzez pobudzanie, popieranie, koordynację ich działań z działaniami innych grup w celu osiągnięcia dobra wspólnego ${ }^{22}$.

Bardzo ważnym aspektem reguły subsydiarności jest jej funkcja wychowawcza, która powinna zaznaczać się w tych wszystkich dziedzinach funkcjonowania zbiorowości ludzkich, gdzie ważne są takie atrybuty, jak samodzielność, inicjatywa, aktywność własna, odpowiedzialność i demokratyzacja ${ }^{23}$. Norma pomocniczości zakłada również kształtowanie postaw pluralistycznego społeczeństwa względem dobra wspólnego. Postawy dotyczące wartości wspólnych nie powinny być kształtowane wyłącznie z „góry do dołu”, ale także „,z dołu do góry”. Oznacza to, że autentyczne przekonania i oceny wartościujące członków społeczeństwa, świadczące o odpowiedzialności za dobro wspólne, powinny mieć wpływ na porządek i kierownictwo życia zbiorowego ${ }^{24}$.

21 J. HÖFFNER, Chrześcijańska nauka społeczna, s. 57-58.

${ }^{22}$ F. MAzureK, Społeczne prawa człowieka, „Roczniki Nauk Społecznych” 10(1982), s. 228; A. ZWoliŃSKI, Zbiorowy obowiazek. Zarys katolickiej nauki społecznej, Kraków 2000, s. 85; W. PIWowARSKI, Zasada pomocniczości w Kościele, s. 42-60.

${ }^{23}$ W. PIWOWARSKI, Zasada pomocniczości a demokracja życia kościelnego, s. 15-16; TENŻE, Interpretacja zasady pomocniczości w literaturze wspótczesnej, „Roczniki Filozoficzne” 12(1964), z. 2, s. 89-94; TENŻE, Pomoc dla samopomocy w świetle katolickiej nauki spotecznej, „Roczniki Nauk Społecznych” 14(1986), z. 1, s. 25-45.

${ }^{24}$ TENŻE, Zasada pomocniczości a demokracja życia kościelnego, s. 18; TENŻE, Zasada pomocniczości w Kościele, s. 82-90. 


\section{ZASADA POMOCNICZOŚCI W KSZTAŁTOWANIU POSTAW SPOŁECZNYCH W OPINII RODZIN PODOPIECZNYCH HOSPICJUM}

Zmiana stosunku do śmierci - w tym również przyjęcie odpowiedzialności za los ludzi umierających przez ogół społeczeństwa - stanowi efekt stosowania reguły pomocniczości $w$ jej aspekcie pedagogicznym. Oddziaływania wychowawcze, mające na celu propagowanie idei hospicyjnej, powinny być skierowane do dwóch kategorii adresatów: potencjalnych członków zespołów hospicyjnych oraz ogółu społeczeństwa.

W propagowaniu holistycznej opieki nad umierającymi duże znaczenie posiada działalność naukowo-dydaktyczna szkół wyższych, przede wszystkim kształcenie przed- i podyplomowe lekarzy, pielęgniarek, psychologów i pracowników socjalnych.

Istotnym zagadnieniem jest także edukacja wolontariuszy, polegająca na wykładach i/lub warsztatach prowadzonych przez doświadczonych członków zespołów hospicyjnych ${ }^{25}$. Udział w szkoleniach umożliwia uczestnikom zapoznanie się z działalnością ruchu hospicyjnego i wymaganiami opieki paliatywnej, a także pozwala ocenić swoje możliwości $\mathrm{w}$ pracy $\mathrm{z}$ osobami terminalnie chorymi ${ }^{26}$.

Ze względu na wzrastającą liczbę przypadków chorób nowotworowych i niedostateczną liczbę profesjonalistów specjalizujących się w opiece paliatywnej wciąż istnieją niedobory kadrowe w zakresie świadczenia pomocy hospicyjnej. W opinii członków rodziny umierających pacjentów istnieje potrzeba specjalistycznego kształcenia czterech kategorii środowisk, z których mogą wywodzić się specjaliści zajmujący się opieką hospicyjną - praktykujący lekarze, pielęgniarki, studenci medycyny oraz przedstawiciele innych zawodów ${ }^{27}$. Największe poparcie wśród ankietowanych uzyskali studenci medycyny $(59,0 \%)$ jako kategoria osób, w stosunku do których istnieje największa potrzeba kształcenia w zakresie sprawowania opieki nad pacjentami znajdującymi się w terminalnej fazie choroby. Dowartościowanie tego środowiska wynika z dwóch przesłanek. Po pierwsze, są to osoby, które zdobywają wiedzę i umiejętności w zakresie ratowania życia człowieka. Po drugie, studenci

\footnotetext{
${ }^{25}$ Szkolenie w zakresie podstaw opieki paliatywno-hospicyjnej, styczeń 2018. Hospicjum Dobrego Samarytanina, www.hospicjum-samarytanin.pl (z dnia 8.11.2018).

${ }^{26}$ Hospicjum Dobrego Samarytanina w Lublinie. Kurs dla wolontariuszy, 30 listopada 2016 - 26 marca 2017. Kronika Hospicjum Dobrego Samarytanina w Lublinie, Lublin 1990, mps.

${ }^{27}$ Badania własne przeprowadzone w Hospicjum Dobrego Samarytanina w Lublinie w latach 2010-2017.
} 
nie posiadają jeszcze określonej specjalizacji medycznej. W związku z tym czas pobierania nauki jest dogodnym momentem, aby podjąć decyzję o specjalizowaniu się w dziedzinie medycyny paliatywnej. Opinia respondentów w kwestii potrzeby specjalistycznego kształcenia dwóch kolejnych środowisk - lekarzy $(61,8 \%)$ i pielęgniarek $(49,0 \%)$ - wskazuje na brak dostatecznej liczby tego rodzaju specjalistów w zespołach zajmujących się pomocą hospicyjną. Rozszerzenie kształcenia w zakresie podnoszenia jakości życia pacjentów w terminalnej fazie choroby wśród lekarzy i pielęgniarek powinno przyczynić się do redukcji hospicyjnych deficytów kadrowych. Niski odsetek respondentów $(11,3 \%)$ wskazuje również na konieczność edukacji w dziedzinie opieki paliatywnej innego rodzaju specjalistów - przede wszystkim duchownych, pracowników socjalnych i psychologów.

Analiza uzyskanych wyników w kontekście struktury płci wskazuje, że większy odsetek mężczyzn zauważa potrzebę kształcenia w zakresie opieki paliatywnej dwóch kategorii podmiotów - studentów medycyny (mężczyźni: 74,9\%; kobiety: 59,8\%) i lekarzy (mężczyźni: 61,3\%; kobiety: 51,0\%). Natomiast większy odsetek kobiet zwraca uwagę na konieczność specjalistycznej edukacji pielęgniarek (kobiety: 50,6\%; mężczyźni: 42,8\%) oraz profesjonalistów zajmujących się oddziaływaniami niemedycznymi w obszarze pomocy hospicyjnej (kobiety: 10,1\%; mężczyźni: 5,4\%).

Uwzględnienie struktury wieku respondentów skłania do konkluzji, że grupa najmłodsza preferuje specjalistyczne kształcenie dwóch kategorii podmiotów - studentów medycyny $(51,0 \%)$ i pielęgniarek (43,0\%). Badani między 26. a 50. rokiem życia oprócz przedstawionych kategorii, dodatkowo dowartościowują edukację lekarzy w dziedzinie medycyny paliatywnej. Świadczy o tym poparcie ok. 1/2 tej populacji dla poglądu, iż w zakresie opieki hospicyjnej należy kształcić studentów medycyny (58,3\%), pielęgniarki $(49,0 \%)$ i lekarzy $(48,9 \%)$. W grupie wiekowej 51-70 lat również zaznacza się dowartościowanie specjalistycznego kształcenia wymienionych grup zawodowych. Jednak można zauważyć, że w stosunku do preferencji młodszych respondentów zwiększa się ukazanie konieczności kształcenia studentów $(67,9 \%)$ i lekarzy $(61,5 \%)$, a jednocześnie spada poparcie edukacji pielęgniarek $(41,7 \%)$. W grupie najstarszych ankietowanych utrzymuje się podobna tendencja, gdyż największą aprobatę uzyskał pogląd odnoszący się do specjalistycznego kształcenia studentów (49,7\%) i lekarzy (53,6\%), zaś mniejsze uznanie zdobyła opinia dotycząca specjalizowania się pielęgniarek w opiece paliatywnej $(39,8 \%)$.

Kolejnych informacji dostarcza rozkład wyników uwzględniający rodzaj obserwowanej pomocy hospicyjnej. Respondenci, uczestniczący w działaniach 
zespołów opieki stacjonarnej, zauważają większą potrzebę profesjonalnego kształcenia specjalistów w zakresie każdej wyszczególnionej kategorii - studentów medycyny (opieka stacjonarna: 63,1\%; domowa: 45,8\%), lekarzy (pomoc stacjonarna: $53,9 \%$; domowa: $37,5 \%$ ), pielęgniarek (opieka stacjonarna: 48,7\%; domowa: 37,5) oraz innych specjalistów (pomoc stacjonarna: 9,2\%; domowa: 4,2\%). Uzyskana prawidłowość może wynikać z faktu, że ankietowani, którzy uczestniczą w oddziaływaniach stacjonarnych zespołów pomocowych, mają większą możliwość obserwowania potrzeb konających pacjentów i deficytów kadrowych w zespołach hospicyjnych niż respondenci korzystający ze wsparcia świadczonego przez zespoły opieki domowej.

Ponad 1/3 badanych $z$ najkrótszym stażem hospicyjnym preferuje specjalistyczne kształcenie trzech kategorii podmiotów w zakresie opieki paliatywnej - studentów medycyny $(41,9 \%)$, lekarzy $(34,9 \%)$ i pielęgniarek $(34,9 \%)$. Styczność ze wspólnotami pomocowymi do 1 miesiąca przyczynia się do wzrostu poparcia dla stanowiska, iż należy kształcić specjalistów w każdej z wymienionych kategorii - studentów medycyny $(66,7 \%)$, lekarzy $(57,1 \%)$, pielęgniarki $(47,6 \%)$ i profesjonalistów reprezentujących zawody niemedyczne w pomocy hospicyjnej (14,3\%). Jeszcze większa preferencja przedstawionego poglądu zaznacza się u ankietowanych, którzy mają średnio- i długoterminowy kontakt ze wspólnotami hospicyjnymi. Świadczy o tym fakt, że za kształceniem studentów w zakresie medycyny paliatywnej opowiada się ok. 3/4 respondentów z tych grup (średni okres kontaktów: 76,0\%; długi: 72,7\%), za podnoszeniem kwalifikacji lekarzy ponad $1 / 2$ obydwu populacji (średni okres kontaktów: 64,0\%; długi: 63,6\%), natomiast za edukacją pielęgniarek 52,0\% grupy mającej średnioterminową styczność z hospicyjnymi zespołami pomocowymi i 72,7\% populacji odznaczającej się długoterminowością tego rodzaju kontaktów. Zaprezentowane powyżej zależności pozwalają zatem sformułować wniosek, że dłuższa styczność z działalnością ruchu hospicyjnego sprzyja dowartościowaniu poglądu, iż należy kształcić większą liczbę osób specjalizujących się w opiece paliatywnej - głównie lekarzy i pielęgniarki.

Wychowanie społeczeństwa do postawy afirmującej godne umieranie uzasadnia zarówno niewielka znajomość problematyki choroby terminalnej, jak również stereotypy dotyczące opieki paliatywnej. Badania wskazują, że umierających pacjentów unika się w większym stopniu niż ludzi z dyskryminowanych grup społecznych ${ }^{28}$. Znaczenie ogólnospołecznej edukacji w tym wzglę-

${ }^{28}$ R. KALITH, Rodzina wobec śmierci, w: Śmierć i umieranie, red. L. Pearson, Warszawa 1973, s. 80; A. DYCZYŃSKA-HERMAN, Aktualne potrzeby i możliwości niesienia ulgi w cierpieniu, „Terminalnie chory - hospicjum” 1996, nr 7, s. 23. 
dzie dostrzegają wspólnoty tworzące ruch hospicyjny. Przykładowo, w Statucie Lubelskiego Towarzystwa Przyjaciół Chorych „Hospicjum Dobrego Samarytanina” znajduje się zapis (art. 8), że „Towarzystwo propaguje ideę i metody opieki nad ludźmi ciężko chorymi i osamotnionymi, zwłaszcza znajdującymi się w końcowym okresie życia [...] poprzez organizację kursów, konferencji i seminariów dla swych członków i sympatyków, a także rozwija propagandę i udziela informacji w zakresie swej działalności statutowej, współdziałając z prasą, radiem i telewizją, wydając własne wydawnictwa oraz stosując inne środki w tym zakresie". Istotnym wkładem w powyższy kierunek stanowią wygłaszane homilie w dniach hospicyjnych w lubelskich parafiach katolickich $^{29}$. Inicjatywa ta zatacza coraz szersze kręgi i zjednuje wiele środowisk duszpasterskich.

W wyniku inicjatyw, mających na celu propagowanie opieki paliatywnej w Polsce, nastąpił rozwój działalności wydawniczej. Jej przykładem są pozycje wydawane przez „Bibliotekę Fundacji Hospicyjnej” czy dwumiesięcznik „Hospicjum to też Życie”. Szeroko pojęta edukacja społeczeństwa w zakresie idei i działalności ruchu hospicyjnego odbywa się również poprzez środki społecznego przekazu ${ }^{30}$. Ich wykorzystywanie w wychowaniu do godnej śmierci jest wskazane $\mathrm{z}$ dwóch powodów. Po pierwsze, media promują wśród swoich odbiorców przede wszystkim młodość, siłę, sprawność, rywalizację, dobrobyt materialny i sukces. Po drugie, śmierć jest ukazywana w sposób nienaturalny - albo drastycznie, albo karykaturalnie ${ }^{31}$. Zarówno codzienne informacje o wypadkach i kataklizmach, jak również filmy przesycone zabójstwami sprawiają, że śmierć nie skłania odbiorców do refleksji ${ }^{32}$. Natomiast zbyt rzadko pojawiają się treści wskazujące na fakt, że umieranie stanowi nieodzowny i naturalny element egzystencji człowieka.

W analizie empirycznej zwrócono uwagę na stosunek najbliższego otoczenia umierających pacjentów do możliwości kształtowania postaw ogólnospołecznych wobec cierpienia i śmierci. Respondentom zadano pytanie dotyczące takich form oddziaływań, które mogą przyczynić się do przyjęcia w społeczeństwie odpowiedzialności za los ludzi umierających.

${ }^{29}$ E. i T. KAMIŃSCY, Gdy rodzi się dobro - rodzi się Bóg, „Głos św. Antoniego. Miesięcznik parafii św. Antoniego Padewskiego w Lublinie", 2018, nr 2, s. 17.

30 J. MAJKA, Katolicka nauka społeczna. Studium historyczno-doktrynalne, Rzym 1986, s. 343.

${ }^{31}$ M. GóRECKI, Hospicjum w stużbie umierajacym, Warszawa 2000, s. 10.

32 A. BARtoszeK, Cztowiek w obliczu cierpienia i umierania. Moralne aspekty opieki paliatywnej, Katowice 2000, s. 45. 
Według osób, stanowiących najbliższe otoczenie podopiecznych hospicjum, istnieją różnorodne sposoby oddziaływania na środowisko społeczne, które moga przyczynić się do dojrzałych postaw wobec cierpienia i śmierci współpraca z różnorodnymi instytucjami, działalność naukowa i wydawnicza, edukacja w środkach masowego przekazu, wychowanie młodzieży szkolnej, a także promocja opieki paliatywnej. Rozkład uzyskanych wyników przekonuje jednak, że za najbardziej skuteczne formy edukacji ogólnospołecznej ankietowani uważają odpowiednie programy w środkach masowej informacji $(52,0 \%)$ i wszelką działalność promującą opiekę paliatywną $(44,0 \%)$. Ponad $1 / 4$ badanych $(28,0 \%)$ preferuje stanowisko, że efektywność w zakresie zmiany stosunku społeczeństwa do problematyki umierania jest związana $z$ edukacją szkolną. Pozostałe formy oddziaływań wychowawczych popiera mniej niż 1/5 respondentów: współpracę z instytucjami - 18,0\%, działalność naukową - 16,0\% i wydawniczą - 15,0\%.

Szczegółowych informacji dotyczących sposobów kształtowania odpowiedzialności społeczeństwa za los ludzi umierających dostarcza rozkład wyników uwzględniający u osób badanych płeć, wiek, rodzaj obserwowanej opieki hospicyjnej i okres styczności ze wspólnotami świadczącymi opiekę paliatywną.

Analiza danych w kontekście struktury płci ankietowanych wskazuje, że większy odsetek mężczyzn niż kobiet preferuje - jako skuteczne metody zmiany postaw ogółu społeczeństwa wobec cierpienia i śmierci - trzy sposoby oddziaływań: wychowanie szkolne (mężczyźni: 38,6\%; kobiety: 28,7\%), nadawanie programów edukacyjnych w środkach masowego przekazu (mężczyźni: 54,8\%; kobiety: 47,1\%) oraz działalność naukową (mężczyźni: 18,4\%; kobiety: 16,2\%). Natomiast kobiety częściej popierają stanowisko, że efektywność kształtowania postaw ogólnospołecznych w analizowanym zakresie zależy od promocji opieki paliatywnej (kobiety: 45,2\%; mężczyźni: 38,8\%), działalności wydawniczej (kobiety: 15,9\%; mężczyźni: 9,1\%) i współpracy z różnorodnymi instytucjami (kobiety: 19,4\%; mężczyźni: 16,9\%).

Powyższe dane pozwalają na sformułowanie konkluzji, że niezależnie od grupy wiekowej, ankietowani zwracają uwagę na dwie formy skutecznych oddziaływań wychowawczych w stosunku do ogółu społeczeństwa w zakresie kształtowania konstruktywnego stosunku wobec terminalnie chorych - edukację w mediach i wszechstronną promocję opieki paliatywnej. Poparcie dla programów edukacyjnych waha się granicach od 40,0\% (w grupach najmłodszych i najstarszych ankietowanych) do 51,2\% (populacja między 51. a 70. rokiem życia). Natomiast za promowaniem opieki paliatywnej najczęściej 
opowiadają się najstarsi respondenci $(50,0 \%)$, a najrzadziej - grupa wiekowa między 26. a 50. rokiem życia $(30,1 \%)$.

Interesujących wniosków dostarcza również rozkład wyników w kontekście rodzaju obserwowanej przez ankietowanych pomocy hospicyjnej. Większy odsetek respondentów uczestniczących w opiece stacjonarnej w stosunku do obserwatorów wsparcia domowego preferuje wszystkie wyszczególnione formy oddziaływań mające na celu kształtowanie postaw społeczeństwa w kierunku podnoszenia jakości życia terminalnie chorych i ich godnego umierania. Największe dysproporcje dotyczą trzech kategorii: promocji opieki paliatywnej (pomoc stacjonarna: 47,0\%; domowa: 28,3\%), programów edukacyjnych w środkach masowego przekazu (opieka stacjonarna: 51,9\%; domowa: 42,9\%) i współpracy z różnorodnymi instytucjami (opieka stacjonarna: $24,2 \%$; domowa: $13,9 \%$ ), zaś mniejsze różnice między porównywanymi grupami zaznaczają się przy poparciu dla edukacji szkolnej (pomoc stacjonarna: 31,6\%; domowa: $24,9 \%$ ) oraz preferowaniu działalności wydawniczej (opieka stacjonarna: 17,1\%; domowa: 9,2\%) i naukowej (opieka stacjonarna: 16,9\%; domowa: 11,9\%). W związku z powyższym można stwierdzić, że obserwacje stacjonarnej pomocy hospicyjnej przyczyniają się w większym stopniu niż uczestnictwo w trosce domowej do ugruntowania poglądu, że dzięki stosowaniu różnorodnych strategii można doprowadzić do zwiększania odpowiedzialności społeczeństwa za los ludzi umierających.

Badanie opinii respondentów z uwzględnieniem okresu ich styczności ze wspólnotami hospicyjnymi wskazuje, że znaczny odsetek osób charakteryzujących się najkrótszym stażem w tym zakresie popiera różnorodne formy kształtowania postaw ogólnospołecznych wobec konających. Ponad 1/2 tej grupy opowiada się za edukacją w mediach $(57,5 \%)$ i promowaniem opieki paliatywnej $(59,12 \%)$, ponad $1 / 3$ popiera wykorzystanie do tych celów edukacji szkolnej (35,3\%), ok. 1/4 - preferuje współpracę z instytucjami $(26,0 \%)$, a ok. 1/5 wskazuje na działalność naukową $(22,3 \%)$ jako ważny środek w działaniach służących zmianie stosunku społeczeństwa wobec cierpienia i śmierci. W grupie odznaczającej się dłuższymi kontaktami z ruchem hospicyjnym (do 1 miesiąca) przedstawione tendencje ulegają dewaluacji. Świadczy o tym fakt, że za programami edukacyjnymi opowiada się $47,6 \%$ tej populacji, za promocją opieki paliatywnej $-42,8 \%$, za edukacją szkolną $-28,6 \%$. Pozostałe formy oddziaływań wychowawczych zyskały aprobatę niewielkiego odsetka ankietowanych - współpraca z instytucjami u 21,2\% respondentów, a działalność wydawnicza i naukowa u 14,9\% tej grupy. Tendencja dewaluacyjna jeszcze silniej zaznacza się w populacji osób, które charakteryzują się średnioterminowym okresem styczności z ruchem hospicyjnym. W tej grupie 
tylko ok. 1/3 badanych popiera dwie formy działalności mającej na celu kształtowanie stosunku społeczeństwa do umierających - edukację w mediach $(32,0 \%)$ i promocję opieki paliatywnej $(32,0 \%)$. Edukację szkolną w tym zakresie akceptuje jedynie $1 / 5$ ankietowanych $(20,0 \%)$. Za pozostałymi strategiami wychowawczymi - współpracą z instytucjami oraz działalnością naukową i wydawniczą - opowiada się tylko $12,0 \%$ tej grupy. Długoterminowa styczność służy zmniejszeniu poparcia dla możliwości kształtowania stosunku społeczeństwa do umierających $\mathrm{w}$ wyniku promowania opieki paliatywnej (27,3\%), edukacji szkolnej $(18,2 \%)$, współpracy z instytucjami $(9,1 \%)$ oraz działalności wydawniczej $(9,1 \%)$. Respondenci, odznaczający się długoterminową stycznością z ruchem hospicyjnym, preferują przede wszystkim nadawanie programów edukacyjnych w środkach masowego przekazu jako skuteczną metodę kształtowania odpowiedzialności społeczeństwa za los konających. Za wymienioną strategią opowiedziało się $45,4 \%$ tej populacji. Ukazane powyżej prawidłowości stanowią podstawę do konkluzji, że krótsze kontakty członków rodziny umierających pacjentów ze wspólnotami hospicyjnymi przyczyniają się do poglądu, że zmiana stosunku społeczeństwa do śmierci może nastąpić w wyniku stosowania różnych strategii edukacyjnych. Natomiast dłuższe doświadczenia hospicyjne prowadzą do większego sceptycyzmu w zakresie możliwości kształtowania postaw społecznych w analizowanym wymiarze.

Zasada pomocniczości stanowi podstawę do promocji społecznych hospicjów, w znacznym stopniu korzystając z naturalnego kapitału inicjatyw obywatelskich i postaw prospołecznych. Wpływa ona również na usuwanie barier między zdrowymi i chorymi, a szczególnie umierającymi. Wyniki badań własnych wśród osób stanowiących najbliższe otoczenie podopiecznych hospicjum wskazują na istniejące sposoby oddziaływania na środowisko społeczne, które moga przyczynić się do dojrzałych postaw wobec cierpienia i śmierci - współpraca z różnorodnymi instytucjami, działalność naukowa i wydawnicza, edukacja w środkach masowego przekazu, wychowanie młodzieży szkolnej, a także promocja opieki paliatywnej.

\section{BIBLIOGRAFIA}

BARToszek A., Człowiek w obliczu cierpienia i umierania. Moralne aspekty opieki paliatywnej, Katowice 2000.

BorUtKa T., MAZUR J., ZwolińSKi A., Katolicka nauka społeczna, Częstochowa 2004.

Ból i cierpienie. Ognisko światła i ciemności, Medycyna-Filozofia-Teologia, red. D. Pater, Warszawa 2015. 
BRZEZIŃSKI M., Służba terminalnie chorym w Nowej Karcie Pracowników Służby Zdrowia, „Zeszyty Naukowe Caritas” 2018, nr 6, s. 45-58.

DYCZYŃSKA-HERMAN A., Aktualne potrzeby i możliwości niesienia ulgi w cierpieniu, „Terminalnie chory - hospicjum" 1996, nr 7.

GÓRECKI M., Hospicjum w służbie umierającym, Warszawa 2000.

Hospicjum Dobrego Samarytanina w Lublinie. Kurs dla wolontariuszy, 30 listopada 2016 26 marca 2017. Kronika Hospicyjna, mps.

HÖFFNER J., Chrześcijańska nauka społeczna, Warszawa 1999.

KALINOWSKI M., Wspólnoty nadziei. Realizacja zasad życia społecznego w ruchu hospicyjnym, Lublin 2007.

KALITH R., Rodzina wobec śmierci, w: Śmierć i umieranie, red. L. Pearson, Warszawa 1973.

KAMIŃSCY E. i T. Gdy rodzi się dobro - rodzi się Bóg, „Głos św. Antoniego”. Miesięcznik parafii św. Antoniego Padewskiego w Lublinie, 2018, nr 2, s. 17.

KoPEREK J., Zasady życia społecznego, w: Słownik społeczny, red. B. Szlachta, Kraków 2004.

MAJKA J., Etyka społeczna i polityczna, Warszawa 1993.

MAJKA J., Katolicka nauka społeczna. Studium historyczno-doktrynalne, Rzym 1986.

MAZUREK F., Społeczne prawa człowieka, „Roczniki Nauk Społecznych” 10(1982).

NAGÓRnY J., Posłannictwo chrześcijan w świecie współczesnym, Świat i wspólnota, t. 1, Lublin 1998.

Noszczyk G., Państwo, w: Jan Paweł II. Encyklopedia nauczania społecznego, red. A. Zwoliński, Radom 2005.

PAPIESKa RAdA DS. SŁUŻBy ZdRowia, Nowa Karta Pracowników Służby Zdrowia, Katowice 2017.

PATER H.D., Holistyczna koncepcja człowieka chorego, Teologia-Medycyna-Praktyka, Warszawa 2017.

PIWOWARSKI W., Zasada pomocniczości w Kościele, w: Kościół - świat - świeccy, Warszawa 1988.

PIWOWARSKI W., Interpretacja zasady pomocniczości w literaturze współczesnej, „Roczniki Filizoficzne" 12(1964), z. 2.

PIWOWARSKI W., Pomoc dla samopomocy w świetle katolickiej nauki społecznej, „Roczniki Nauk Społecznych" 14(1986), z. 1.

PIWOWARSKI W., Zasada pomocniczości w demokratyzacji życia kościelnego, „Roczniki Teologiczno-Kanoniczne" 35(1988), z. 6.

PIWOWARSKI W., Zasada pomocniczości, w: Słownik katolickiej nauki społecznej, red. W. Piwowarski, Instytut Wydawniczy PAX, Warszawa 1993.

STRZESZEWSKI Cz., Katolicka nauka społeczna, Lublin 1994.

SzoT L., Obecni do końca, Warszawa 2010.

WoJTYŁa K., Katolicka etyka społeczna, Lublin 2018.

ZWOLIŃSKI A., Zbiorowy obowiązek, Zarys katolickiej nauki społecznej, Kraków 2000. 


\title{
ZASADA POMOCNICZOŚCI W PROMOCJI SPOŁECZNYCH HOSPICJÓW W POLSCE NA PODSTAWIE BADAŃ WŁASNYCH
}

\author{
S t r e s z c z e n i e
}

Działalność ośrodków paliatywno-hospicyjnych w Polsce i w większości krajów wysoko rozwiniętych już od dekady ewoluuje w stronę wyspecjalizowanych placówek świadczących pomoc osobom w terminalnej fazie choroby nowotworowej. Stanowią one część systemu opieki zdrowotnej danego kraju, spełniając wszystkie kryteria zakładów opieki leczniczej. Zasada pomocniczości stanowi podstawę do promocji społecznych hospicjów, w znacznym stopniu korzystając z naturalnego kapitału inicjatyw obywatelskich i postaw prospołecznych. Wpływa ona również na usuwanie barier między zdrowymi i chorymi, a szczególnie umierającymi. Artykuł przedstawia wyniki badań własnych wśród osób stanowiących najbliższe otoczenie podopiecznych hospicjum. Respondenci wskazują na istniejące sposoby oddziaływania na środowisko społeczne, które mogą przyczynić się do dojrzałych postaw wobec cierpienia i śmierci - współpraca z różnorodnymi instytucjami, działalność naukowa i wydawnicza, edukacja w środkach masowego przekazu, wychowanie młodzieży szkolnej, a także promocja opieki paliatywnej.

Słowa kluczowe: zasada pomocniczości; hospicja w Polsce. 